\title{
Phytochemical Screening and Antimicrobial Activities of Methanolic and Aqueous Leaf Extracts of Carica papaya Grown in Rwanda
}

\author{
Cyuzuzo Callixte ${ }^{1}$, Nsanzimana Jean Baptiste $^{1,2}$, Heny Arwati $^{3}$ \\ ${ }^{1}$ Department of Immunology, School of Postgraduate, Universitas Airlangga, Surabaya, Indonesia \\ ${ }^{2}$ College of Science and Technology, University of Rwanda, Kigali, Rwanda \\ ${ }^{3}$ Department of Parasitology, Faculty of Medicine, Universitas Airlangga, Surabaya, Indonesia
}

Background: Nowadays, microbial infections remain as the leading cause of infectious diseases and human death worldwide. The use of plant-derived medicines is currently increasing in the treatment of various diseases. Papaya leaves have proteolytic enzymes and phytoconstituents with antimicrobial properties. Rwandan citizens use papaya leaves to treat hair dandruff, wounds and burns.

Materials and Methods: Papaya leaves were collected and allowed to dry under the shed at room temperature for 14 days. The powdered plant materials were soaked separately in clean flask and extracted successively using maceration method with water and methanol. Qualitative phytochemical screening was conducted by using specific standard procedures. Antimicrobial activity assays of all the extracts were performed by agar well diffusion method and determined by measuring the zones of inhibition with transparent scale.

Results: Phytochemical screening revealed the presence of alkaloids, carbohydrates, tannins, flavonoids, steroids and phenolic compounds. In this observation, all the extracts exhibit significant inhibitory activity against all test pathogens ranging from $2 \mathrm{~mm}$ to $26 \mathrm{~mm}$ of diameter. Methanol extracts showed the maximum activity against Candida albicans (inhibition zone: $26 \pm 0.11$ and activity index: 1.23). Minimum inhibition concentration values ranges between $3.175 \mathrm{mg} / \mathrm{mL}$ and $12.5 \mathrm{mg} / \mathrm{mL}$.

Conclusion: The results indicate that Carica papaya leaves could be very potent source of antimicrobial agents and secondary metabolites that can be used by pharmaceutical industries to produce medicines.

Keywords: Carica papaya, antimicrobial, agar well diffusion, phytochemical screening, zone of inhibition, activity index

\section{Introduction}

Carica papaya is a medicinal plant in which one or more parts contain substances that can be used for treatment purposes and the production of drugs. Papaya leaves contain secondary metabolites like alkaloids, $\beta$-carotene, steroids, saponins, glycosides, tannins and flavonoids which have antipathogenic, antitumor and immunomodulatory activities. $^{1}$

Date of submission: March 19, 2019

Last Revised: June 10, 2019

Accepted for publication: June 18, 2019

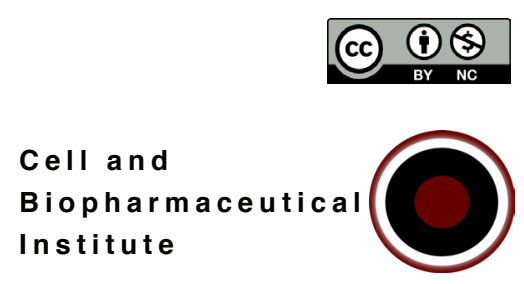

Corresponding Author:

Cyuzuzo Callixte

Institute of Tropical Disease

Universitas Airlangga, Kampus C

Jl. Unair, Mulyorejo, Gubeng, Surabaya, Indonesia

e-mail: cyuzuzocallixte@gmail.com 
Carica papaya leaves contain bioactive compounds; papain and chymopapain which help in digestion and inhibit greatly the life processes of different disease- causing microorganisms. ${ }^{2,3}$ Papaya leaves are rich in protease and amylase. These enzymes have high anti-inflammatory properties which reduce the inflammation of stomach and colon. ${ }^{4}$ Papaya leaf extracts heal peptic ulcers by killing bacteria Helicobacter pylori owing to their antimicrobial properties. $^{5}$

Papaya leaves contain carpain, acetogenin and phenolic compounds. Carpain is a chemical compound or a substance with ability to kill microorganisms that often intervene in food digestion processes. ${ }^{1,6}$ It also stops the excess growth of skin flora by sanitizing skin from the toxins and provide protection against skin problems like pimples, freckles and acne. ${ }^{7}$

Acetogenin, a compound which prevents dangerous diseases like malaria, cancers and dengue fever. ${ }^{8}$ Their extracts have ability to cure different intestinal diseases in animal models including amoebiasis and urinogenital disorder like trichomoniasis. ${ }^{9}$ Phenolic compounds such as protocatechuic acid, p-coumaric acid, 5, 7dimethoxycoumarin, caffeic acid, kaempferol, quercetin and chlorogenic acid work singlehandedly or collectively to reduce B16F10 tumor cell growth. ${ }^{10}$ Papaya leaf extracts regenerate the platelets and white blood cells level. ${ }^{11}$ Papaya leaf juice boosts the activation of primary components of immune system like T-lymphocytes which trigger the production of different chemical messengers interleukin (IL)-12, interferon (IFN)- $\gamma$, and tumor necrosis factors (TNF)- $\alpha$ that perform various roles in defense to specific stresses from chemotherapies. ${ }^{12}$ Carica papaya leaf extracts have protective effect against gastric ulcers in rats and inhibit sickle cell formation. They also regulate the production of insulin and bring down the complications of diabetes like kidney damage and fatty liver. ${ }^{13,14}$ The primary objective of this study was to evaluate the antimicrobial activities of methanolic and aqueous leaf extracts of Carica papaya grown in Rwanda.

\section{Materials and methods}

\section{Preparation of Plant Samples}

Healthy disease free, mature fresh Carica papaya leaf samples were collected locally in Tumba sector, Huye district, Southern province, Rwanda. The collected fresh leaves were rinsed thoroughly 2-3 times with running tap water and once with sterile water. The leaves were dried under the shed at room temperature for 14 days. Dried leaves were crushed into powder with the help of mortar and pestle. The powder was stored in sealed and labeled container and kept in dry place to its use for extraction.

\section{Extraction of The Plant Material}

The extraction experiment was aseptically carried out in Biotechnology laboratory at room temperature for 3 days using rotary shaker for better extraction. Twenty grams of dried leaf powder was soaked and macerated successively with $100 \mathrm{~mL}$ each of $70 \%$ methanol and water. After extraction, the extracts were decanted and then filtered through Whatman filter paper. Methanolic crude extract was obtained by evaporating the solvent using rotary evaporator and crude aqueous extract obtained by lyophilization process. ${ }^{1516}$ The extracts were kept in different labeled tubes then stored in the refrigerator at $4{ }^{\circ} \mathrm{C}$ until use.

\section{Materials Sterilization}

In order to avoid any kind of contamination and cross contamination by the test pathogens, all types of precautions were highly maintained. With detergent, glasswares were washed and rinsed properly with distilled water. They were dried under the shed and eventually sterilized in oven at $170^{\circ} \mathrm{C}$. The sterilization of cork borer and forceps were done by immersing them in $70 \%$ ethanol then blazed in Bunsen flame. The inoculating loops were sterilized by heating them to redness using flame before and after each use.

\section{Sterility Proofing of The Extracts}

To confirm the sterility of the extracts, $2 \mathrm{~mL}$ of the extracts were introduced into $10 \mathrm{~mL}$ of Mueller Hinton broth and incubated at $37^{\circ} \mathrm{C}$ for 24 hours. The absence of microorganism growth on the broth after the period of incubation signifies the presence of a sterile extract. After seeing that, there was no need of sterilizing the extracts under UV light.

\section{Phytochemical Screening}

Systematic phytochemical screening was used to examine the presence of chemical constituents in crude leaf extracts according to standard method. ${ }^{17}$ The qualitative analysis tests were performed for various bioactive components such as flavonoids (Shinoda's test), steroids (Salkowski test), carbohydrates (Benedict's test), tannins (Ferric chloride test), alkaloids (Wagner's test) and phenolic compounds were examined by diluting the extract with distilled water 
up to $5 \mathrm{~mL}$ and added 3 drops of $5 \%$ ferric chloride solution. The presence of phenolic compounds was confirmed by the change in colors to dark green.

\section{Test Microorganisms}

The microorganisms used in this study were all human pathogens from clinical specimens. Pure cultures of Escherichia coli, Staphylococcus aureus and Candida albicans used to assess the antimicrobial properties were obtained from Bacteriology Department in clinical laboratory of University Teaching Hospital of Butare. The microorganisms were collected on sterile plate and incubated at $37^{\circ} \mathrm{C}$ for 24 hours. A single colony of each microorganism was diluted in $9 \mathrm{~mL}$ of peptone water and eventually used to test the antimicrobial potencies of the obtained extracts.

\section{Antibacterial and Antifungal Assay of Extracts}

The antimicrobial assay of extracts was examined by agar well diffusion method according to National Committee for Clinical Laboratory Standards. ${ }^{18} 25 \mu \mathrm{L}$ of diluted microorganisms were swabbed on respective nutrient agar plates. After spreading, Pasteur pipette was used to create 3 wells in the inoculated agar and filled up with $25 \mathrm{mg} / \mathrm{mL}$, $50 \mathrm{mg} / \mathrm{mL}$ and $100 \mathrm{mg} / \mathrm{mL}$, respectively. Ciprofloxacin (10 $\mathrm{mg} / \mathrm{mL}$ ) solution was used as standard. The plates were incubated in the upright position at $37^{\circ} \mathrm{C}$. Staphylococcus aureus and Escherichia coli plates were incubated for 24 hours and Candida albicans was incubated for 72 hours. After incubation, the antimicrobial activities of the test materials were determined by measuring the diameter of inhibition zones in millimeter with a transparent scale. Three replicates were carried out for each extract against each of the test microorganism. Data were recorded as mean \pm standard deviation. The activity index for each extract was calculated by using the following formula:

Activity index $=\frac{\text { Inhibition zone of the sample }}{\text { Inhibition zone of the standard }}$

\section{Determination of Minimum Inhibition Concentration (MIC)}

The MIC is defined as the lowest concentration that inhibits the visible growth of pathogens after overnight incubation. In this study, the MIC was examined by preparing the inoculum of microorganisms from nutrient broth cultures. With broth dilution technique, the plant extracts were prepared to the highest concentration of $100 \mathrm{mg} / \mathrm{mL}$ in propanol and diluted to the smallest concentration to check the MIC. The extracts were serially diluted from $100 \mathrm{mg} /$ $\mathrm{mL}$ to $0.195 \mathrm{mg} / \mathrm{mL}$ with $2 \mathrm{~mL}$ of distilled water. One $\mathrm{mL}$ suspension of the test microorganisms was inoculated with Mueller Hinton broth as a positive control and Ciprofloxacin as a standard reference antibiotic. It was incubated for 1820 hours at $37^{\circ} \mathrm{C}$ and determined the MIC by observing the presence or absence of turbidity in the test tubes. The least concentration where no turbidity observed was noted as the $\mathrm{MIC}$ value.

\section{Results}

\section{Phytochemical Analysis}

Phytochemical analysis revealed the presence of alkaloids, carbohydrates, tannins, flavonoids, steroids and phenolic compounds in methanolic extracts and absence of alkaloids, steroids and flavonoids in aqueous extracts, as shown in Table 1 .

\section{Antimicrobial Activity}

In the present investigation, methanol and aqueous extracts exhibited considerable antimicrobial activity and indicated the suitability of these solvents for dissolving some bioactive compounds of the plants. Table 2 showed the antimicrobial activity of Carica papaya leaves extracts.

Based on obtained results, methanolic extracts showed the highest activity compared to aqueous extracts. In this observation, the antimicrobial activities of the extracts increased linearly with increase in concentration of extracts $(\mathrm{mg} / \mathrm{mL})$.

Table1. The results of the chemical tests of the Carica papaya leaf extracts.

\begin{tabular}{lccccc}
\hline Plant Extracts & Alkaloids & Carbohydrates & Tannins & Flavonoids & $\begin{array}{c}\text { Steroids } \\
\text { Compounds }\end{array}$ \\
\hline Methanolic extract & + & + & + & + & + \\
\hline Aqueous extract & - & + & + & - & - \\
\hline
\end{tabular}


Table 2. Antimicrobial activity of leaves extracts of Carica papaya.

\begin{tabular}{|c|c|c|c|c|}
\hline \multirow[b]{2}{*}{ Microorganisms } & \multirow{2}{*}{$\begin{array}{c}\text { Concentrations } \\
\text { of Extracts } \\
(\mathrm{mg} / \mathrm{mL})\end{array}$} & \multicolumn{3}{|c|}{ Zone of Inhibition (mm) } \\
\hline & & Methanolic Extracts & Aqueous Extracts & $\begin{array}{c}\text { Ciprofloxacin } \\
10 \mathrm{mg} / \mathrm{mL}\end{array}$ \\
\hline \multirow{3}{*}{ Staphylococcus aureus } & 25 & $8 \pm 0.2$ & $2 \pm 0.37$ & \multirow{3}{*}{$23 \pm 0.82$} \\
\hline & 50 & $19 \pm 0.5$ & $6 \pm 0.68$ & \\
\hline & 100 & $24 \pm 0.45$ & $12 \pm 0.29$ & \\
\hline \multirow{3}{*}{ Escherichia coli } & 25 & $6 \pm 0.83$ & $2 \pm 0.74$ & \multirow{3}{*}{$26 \pm 0.46$} \\
\hline & 50 & $13 \pm 0.25$ & $5 \pm 0.39$ & \\
\hline & 100 & $20 \pm 0.61$ & $8 \pm 0.16$ & \\
\hline \multirow{3}{*}{ Candida albicans } & 25 & $5 \pm 0.15$ & $3 \pm 037$ & \multirow{3}{*}{$21 \pm 0.47$} \\
\hline & 50 & $13 \pm 0.03$ & $9 \pm 0.29$ & \\
\hline & 100 & $26 \pm 0.11$ & $15 \pm 0.35$ & \\
\hline
\end{tabular}

\section{MIC}

The MIC in this study ranged between $3.175 \mathrm{mg} / \mathrm{mL}$ and $12.5 \mathrm{mg} / \mathrm{mL}$. The activity index for each extract was obtained by calculating the ratio between inhibition zone of the sample and the inhibition zone of the standard antibiotic (Table 3).

\section{Discussion}

It has been reported that the resistance of different microorganisms is inhibited by bioactive substances that exist in different plant parts. The plant extracts used in this study demonstrated their antibacterial and antifungal properties and prove the importance of medicinal plants. ${ }^{19}$ The present work showed that these extracts contain alkaloids, carbohydrates, flavonoids, tannins, steroids, and phenolic compounds..$^{20}$

The antimicrobial activity is a result of individual or combination of these bioactive compounds which are the sources of newer useful drugs and other pharmacological importance. ${ }^{21}$ The results of this study confirmed the use of plants in production of antibiotics and other pharmaceutical products. It also revealed that the leaf extracts of Carica papaya possess secondary metabolites with antimicrobial properties that can be used by drug manufacturers. ${ }^{22}$ Different researchers have also shown that extracts of some plants inhibited the growth of various microorganisms at different concentrations. They also reported that the antimicrobial actions occur when the bioactive components of the extracts inhibit the cell wall formation and cause the leakage of cytoplasmic constituents. ${ }^{23}$ In the present investigation, the effective antimicrobial activity was found in organic extracts than aqueous extracts because they have great capacity to extract different bioactive compounds depending on their solubility. ${ }^{24}$

The high antimicrobial activity of methanolic extract in this study was due to the presence of tannins, steroids and flavonoids. Other studies showed that these medicinally bioactive components exert antimicrobial action through different biological mechanism. Tannins cause inhibition in the cell wall synthesis by forming irreversible complexes with prolene rich protein. ${ }^{25}$ The steroids and saponins have the ability to cause leakage of proteins and certain enzymes from the cell. ${ }^{26}$ Flavonoids have the ability to complex with extracellular and soluble proteins and to complex with bacterial cell walls. ${ }^{27}$ The difference in antimicrobial activity of these extracts also depends on the quantity of chemical substances present in the plant. The quantity of bioactive compounds presents in the extracts depend on the extracted plant parts. Leaves, roots, fruits, stems and seeds have different quantity of chemical compounds. ${ }^{28}$

The stage of maturity, rainfall, temperature, light variations and gender of the tree (male, hermaphrodite and female) determine the quantity of secondary metabolites present in the extracts which cause difference in their antimicrobial activities. ${ }^{29}$ Other factors that can affect the 
Table 3. The activity index of papaya leaves extracts on pathogens in accordance to Ciprofloxacin as a standard.

\begin{tabular}{|c|c|c|c|}
\hline \multirow[t]{2}{*}{ Microorganisms } & \multirow{2}{*}{$\begin{array}{l}\text { Concentrations } \\
\text { of extracts } \\
(\mu \mathrm{g} / \mathrm{mL})\end{array}$} & \multicolumn{2}{|c|}{$\begin{array}{c}\text { Activity Index } \\
\text { (Inhibition Zone of Extracts/ } \\
\text { Inhibition Zone of Standard) }\end{array}$} \\
\hline & & Methanolic Extracts & Aqueous Extracts \\
\hline \multirow{3}{*}{ Staphylococcus aureus } & 25 & 0.34 & 0.08 \\
\hline & 50 & 0.82 & 0.26 \\
\hline & 100 & 1.04 & 0.52 \\
\hline \multirow{3}{*}{ Escherichia coli } & 25 & 0.23 & 0.07 \\
\hline & 50 & 0.5 & 0.19 \\
\hline & 100 & 0.76 & 0.3 \\
\hline \multirow{3}{*}{ Candida albicans } & 25 & 0,23 & 0.01 \\
\hline & 50 & 0.61 & 0.42 \\
\hline & 100 & 1.23 & 0.71 \\
\hline
\end{tabular}

quantity of plant secondary metabolites include soil salinity, geographical location, environment, and the species of the plant. This is in fair correlation with Munns who reported that soil salinity is one of the abiotic factors that affect the quantity of plant secondary metabolites by hindering water absorption, growth and plant metabolism as well as both physiological and chemical processes. ${ }^{30}$

The bioactive components present in extracts attach to the cell surface and penetrate to the phospholipid bilayer of the cell membrane which influence the cell metabolism to cause cell death. ${ }^{31}$ Both methanolic and aqueous extracts showed potent activities against Staphylococcus aureus with great zone of inhibition. The highest sensitivity of Staphylococcus aureus may be due to its cell wall structure and outer membrane. ${ }^{32}$

The results in this study supported the findings reported by previous study which showed that both water and methanol extracts exerted antibacterial activity on all the strains at different concentrations. ${ }^{33}$ The activity of aqueous extracts in the present investigation is in contrast to the results another study which reported that water may not extract aromatic and saturated antibacterial compounds that can inhibit the growth of microorganisms. ${ }^{34}$ The findings of this research showed that all extracts in general are more effective on Gram-positive bacteria than on Gramnegative bacteria ${ }^{35}$ and agree that it could be explained by the different cell wall structures of these bacteria. Gramnegative outer membrane comprising of phospholipids and lipopolysaccharides act as a barrier to the entrance and reaction of most antibiotics and/or antimicrobial agents through cell envelope. ${ }^{36}$

\section{Conclusion}

The current findings confirmed the presence of bioactive compounds which have the ability to inhibit the growth of microorganisms. They also provided scientific justification that methanol and aqueous leaf extracts of Carica papaya have both antibacterial and antifungal activities on the tested human pathogens. The methanol extracts exhibited the most remarkable activity against pathogens compared to aqueous extracts. The obtained results are the indications that Carica papaya leaf extracts have great medicinal profile which could be considered in production of effective antibiotics against number of microbial diseases. It is clear to recommend a detailed research to be carried out on different extracts of other medicinal plant parts using different solvents.

\section{References}

1. Anibijuwon II, Udeze AO. Antimicrobial activity of papaya on some pathogenic organisms of clinical origin from south-western Nigeria. Ethnobotanical Leaflets. 2009; 2009(7): 850-64. 
2. Unaeze MC, Brikwa PO. Antimicrobial activity of certain medicinal plants used in traditional medicine in Nigeria: Preliminary study. Res J Microbiol. 1986; 6(2): 32-40.

3. Yismaw G, Tessema B, Mulu A, Tiruneh M. The in vitro assessment of antibacterial effect of papaya seed extracts against bacterial pathogens isolated from urine, wound and stool. Ethiop Med J. 2008; 46(1): 71-7.

4. Alabi OA, Harunan MT, Anokwuru CP, Jegede T, Abia H, Okegbe V, et al. Comparative studies on antimicrobial properties of extracts of fresh and dried leaves of Carica papaya (L) on clinical bacterial and fungal isolates. Pelagia Research Library. 2012; 3(5): 3107-14.

5. Tona L, Kambu K, Ngimbi N. Antiamoebic and phytochemical screening of some medicinal plants. 1998; 61(1): 57-65.

6. Calzada F, Yepez-Mulia L, Tapia-Contreras A. Effect of Mexican medicinal plant used to treat trichomoniasis on trichomonas vaginalis. J. Ethnopharmacol. 2007; 113(2): 248-51.

7. Udoh P, Essien I, Udoh F. Effect of Carica papaya (paw paw) seeds extract on the morphology of pituitary-gonadal axis of male Wistar rats. Phytother Res. 2005; 19(12): 1065-8.

8. Ocloo A, Nwokolo NC, Nicholas TKD. Phytochemical characterization and comparative efficacies of crude extracts of Carica papaya. Int J Drug Res Tech. 2012; 2(5): 399-406.

9. Zy EA, Area A, Aam K. Antimicrobial activity of some medicinal plant extracts in Palestine. Pak J Med Sci. 2005; 21: 187-93.

10. Romasi EF, Karina J, Parhusip AJN. Antibacterial activity of papaya leaf extracts against pathogenic bacteria. Makara J Technol. 2011; 15(2): 173-7.

11. Kafaru E. Immense help from natives workshop. 1st Ed. Lagos: Elizabeth Kafaru; 1994.

12. Aravind G, Debjit B, Duraivel S, Harish G. Traditional and medicinal uses of Carica papaya. J Med Plants Stu. 2013; 1(1): 7-15.

13. Satrija F, Nansen P, Murtini S, He S. Anthelmintic activity of Carica papaya latex against patent Heligmosomoides polygyrus infections in mice. J Ethnopharm. 1995; 48(3): 161-4.

14. Indran M, Mahmood AA, Kuppusamy UR. Protective effect of Carica papaya $\mathrm{L}$ leaf extract against alcohol induced acute gastric damage and blood oxidative stress in rats. West Indian Med J. 2008; 57(4): 323-6.

15. Patapoff TW. The importance of freezing on lyophilization cycle development. Biopharm.2002; 3: 16-21.

16. Builders PF. Assessment of the intrinsic and stability properties of the freeze dried and formulated extract of Hibiscus sabdariffa Linn. (Malvaceae). Afr J Pharmacy. 2010; (4)6: 304-13.

17. Edeoga HO, Okwu DE, Mbaebie BO. Phytochemical constituents of some Nigerian medicinal plants. Afr J Biotech. 2005; 4 (7): 685-8.

18. NCCLS. Performance Standards for Antimicrobial Disc Susceptibility Tests. Approved Standard. Villanova: National Committee for Clinical Laboratory Standards; 1993.

19. Mitscher LA, Leu RP, Bathala MS, Wu WN, Beal JL. Antimicrobial agents from higher plants. I. Introduction, rationale, and methodology. Lloydia. 1972; 35(2): 157-66.
20. Hossain MA, Muhammad MD, Charles G, Muhammad I. In vitro total phenolics, flavonoids contents and antioxidant activity of essential oil, various organic extracts from the leaves of tropical medicinal plant Tetrastigma from Sabah. Asian Pac J Trop Med. 2011; 4(9): $717-21$.

21. Srinivasan D, Nathan S, Suresh T, Lakshmana Perumalsamy P. Antimicrobial activity of certain Indian medicinal plants used in folkloric medicine. J Ethnopharm. 2001; 74(3): 217-20.

22. Sherwani SK, Bokhan TZ, Nazim K, Gilani SA, Kazim SU. Qualitative phytochemical screening and antifungal activity against human and plant pathogenic bacteria. Int Res J Pharm. 2013; 4(7): 83-6.

23. Elisabetsy E. A review of pharmacological properties. ECAM. 2006; 3: $39-48$.

24. Akujobi C, Anyanwu BN, Onyeze C, Ibekwe VI. Antibacterial activities and preliminary phytochemical screening of four medicinal plants. J Appl Sci. 2004; 7(3): 4328-38.

25. Mamtha B, Kavitha K, Srinivasan KK, Shivananda PG. An in vitro study of the effect of Centella asiatica [Indian pennywort] on enteric pathogens. Indian J Pharmacol. 2004; 36(1): 41-3.

26. Zablotowicz RM, Hoagland RE, Wagner SC. Effect of saponins on the growth and activity of rhizosphere bacteria. Advances in Experimental Medicine and Biology. 1996; 405: 83-95.

27. Marjorie C. Plant products as antimicrobial agents. Clin Microbiol Rev. 1999; 12(4): 564-82.

28. Ramakrishna A, Ravishankar GA. Influence of abiotic stress signals on secondary metabolites in plants. Plant Signal Behav. 2011; 6(11): 1720-31.

29. Mayrhofer S, Teuber M, Zimmer I, Louis S, Fischbach RJ, Schnitzler JP. Diurnal and seasonal variation of isoprene biosynthesis-related genes in grey poplar leaves. Plant Physiol. 2005; 139(1): 474-84.

30. Munns R. Comparative physiology of salt and water stress. Plant Cell Environ. 2002; 25(2): 239-50.

31. Bajpai VK, Sharma A, Baek KH. Antibacterial mode of action of Cudrania tricuspidata fruit essential oil, affecting membrane permeability and surface characteristics of food borne pathogens. Food Control. 2013; 32: 582-90.

32. Zaika LL. Spices and herbs: their antimicrobial activity and its determination. J Food Saf. 1988; 9(2): 97-118.

33. Akinyemi KO, Oluwa OK, Omomigbehin EO. Antimicrobial activity of crude extracts of three medicinal plants used in south-west Nigerian folk medicine on some food borne bacterial pathogens. Afr J Tradit Complement Altern Med. 2006; 3(4): 13-22.

34. Cowan MM. Plant products as antimicrobial agents. Clin Microbiol Rev. 1999; 12(4): 564-582.

35. Baron EJ, Peterson LR, Finegold SM. Bailey \& Scott's Diagnostic Microbiology. 9th ed. St. Louis: C.V. Mosby; 1994.

36. Lennette EH, Balows A, Hausler WJ, Shadomy HJ. Manual of Clinical Microbiology. 4th ed. Washington DC: American Society for Microbiology; 1985. 